\title{
Immobilized Horseradish Peroxidase on Discs of Polyvinyl Alcohol-Glutaraldehyde Coated with Polyaniline
}

\author{
Samantha Salomão Caramori, ${ }^{1,2}$ Kátia Flávia Fernandes, ${ }^{3}$ \\ and Luiz Bezerra de Carvalho Junior ${ }^{2}$ \\ ${ }^{1}$ Unidade Universitária de Ciências Exatas e Tecnológicas, Universidade Estadual de Goiás, Caixa Postal 459, Rodovia BR 153, \\ Km 9875132-903 Anápolis, GO, Brazil \\ ${ }^{2}$ Departamento de Bioquímica and Laboratório de Imunopatologia Keizo Asami (LIKA), Universidade Federal de Pernambuco, \\ Avenida. Prof. Morais Rego, Campus Universitário, 50670-910 Recife, PE, Brazil \\ ${ }^{3}$ Laboratório de Química de Proteínase, Departamento de Bioquímica e Biologia Molecular, Instituto de Ciências Biológicas, \\ Universidade Federal de Goiás, Caixa. Postal 131, 74001-970 Goiânia, GO, Brazil
}

Correspondence should be addressed to Samantha Salomão Caramori, samantha.salomao@ueg.br

Received 21 October 2011; Accepted 11 December 2011

Academic Editor: Jean-Francois Hausman

Copyright (C) 2012 Samantha Salomão Caramori et al. This is an open access article distributed under the Creative Commons Attribution License, which permits unrestricted use, distribution, and reproduction in any medium, provided the original work is properly cited.

\begin{abstract}
Discs of network polyvinyl alcohol-glutaraldehyde (PVAG) were synthesized and coated with polyaniline (PANI) using glutaraldehyde as a chemical arm (PVAG-PANIG-HRP disc). The best conditions for the immobilization were established as about $1.0 \mathrm{mg} \mathrm{mL}^{-1}$ of protein, for $60 \mathrm{~min}$ and $\mathrm{pH} 5.5$. The soluble enzyme lost all of its activity after incubation at $70^{\circ} \mathrm{C}$ for $15 \mathrm{~min}$, whereas the PVAG-PANIG-HRP disc retained about half of the initial activity for pyrogallol. The same PVAG-PANIGHRP disc was used consecutively three times without any activity lossbut presented $25 \%$ of the initial activity after the 7 th use. PVAG-PANIG-HRP disc retained approximately $80 \%$ and $60 \%$ of its initial activity after 60 and 80 days of storage, respectively. Resorcinol, m-cresol, catechol, pyrogallol, $\alpha$-naphthol, $\beta$ naphthol, and 4, 4' -diaminodiphenyl benzidine were efficiently oxidized by the PVAG-PANIG-HRP disc (from about 70\% to 90\%), and it was less efficient towards aniline, phenol, and 2-nitrosonaphthol.
\end{abstract}

\section{Introduction}

Peroxidases (Enzyme Commission number 1.11.1.7) are a huge family of heme-containing enzymes that catalyze oxidation and reduction reactions of large families of substrates.

Their broad substrate specificity, polyfunctionality, and availability from different sources allow their application in various biotechnological processes. Oxidative destruction of colored compounds is significantly stimulated by peroxidase and it is a practical interest for decoloration processes used in food, textile, and paper industry as well as in washing powders $[1,2]$. Peroxidases have a variety of biotechnology application due to this catalytic mechanism. For instance, they are capable of oxidizing many compounds bearing the functional group $\mathrm{R}-\mathrm{N}=\mathrm{N}-\mathrm{R}^{\prime}$ (azo-dyes), in which $\mathrm{R}$ and $\mathrm{R}^{\prime \prime}$ can be either aryl or alkyl groups. These compounds are widely used in the textile industry and discarded in water collections. They are defined as pollutants because of their mutagenic and carcinogenic effects. Additionally, azo-dyes can cause biological cycles alteration $[3,4]$. Peroxidases are also extensively used in clinical and immunological analysis, such as glucose $[5,6]$, cholesterol $[7,8]$, and urea [9] determinations, procedures involving $\mathrm{H}_{2} \mathrm{O}_{2}$ releasing. Horseradish peroxidase (HRP) is the most popular source among the peroxidases. It can use a variety of organic compounds as donors and acceptors of electron.

The immobilization of these enzymes has been used to enhance the potential applications of them. Immobilized peroxidase obtained from bitter gourd (Momordica charantia) has been reported to present more advantages than the free enzyme in the treatment of wastewater contaminated with phenols [10]. Immobilized Saccharum spontaneum peroxidase [11] and potato polyphenol oxidase [12] have also been proposed to decompose textile dyes. 
Previously in our laboratories, HRP was successfully immobilized on powder of PANIG [13, 14]. This enzymatic derivative presented difficulties to be separated from the reaction mixture. Attempts to overcome the separation step were also conducted by our research group, culminating in the preparation of PET-PANIG composite as strips with immobilized HRP, which could be manually removed from reaction medium. However, this material presented low protein loading [15].

PVAG has been used for protein immobilization because of the plasticity and high surface area of this material [1618]. The hydrophilic behavior of PVA, on the other hand, interferes in the microenvironment of the immobilized protein when nonpolar substrates/products are involved. Moreover, comparisons of PVA and PVA-PANI composites indicated a less immobilization capacity of PVA when it is not covered by PANI [19]. Trying to overcome the limitation of PANI powder and PET-PANI composites, and using the interesting properties of PVA, discs of PVAG covered with PANI are proposed as a matrix for HRP immobilization. The resulting composite was investigated to propose an alternative immobilized HRP preparation to be used in the detoxification of wastewater containing phenolic compounds. Some features affecting the immobilization procedure and properties of this derivative were then investigated.

\section{Materials and Methods}

2.1. Materials. Pyrogallol and catechol were obtained from Sigma-Aldrich (Saint Louis CA, USA). Alpha- and betanaphthol, m-cresol, resorcinol, and phenol were purchased from Vetec Química Fina Ltda. (São Paulo SP, Brazil). Aniline, 2-nitrosonaphthol, 4,4' diamine-diphenylbenzidine were purchased from Merck (Darmstadt, Germany). HRP was kindly provided by Dr. Elba Bon (Universidade Federal do Rio de Janeiro, Rio de Janeiro, Brazil).

2.2. PVAG-PANIG Discs Synthesis. The PVAG-PANIG disc synthesis was based on procedures described by Carvalho et al. [17] and Fernandes et al. [13], modified by Caramori et al. [19]. Briefly $2 \%(\mathrm{w} / \mathrm{v})$ polyvinyl alcohol $(10 \mathrm{~mL})$ was dissolved at $65^{\circ} \mathrm{C}$, and then $2.5 \%(\mathrm{v} / \mathrm{v})$ glutaraldehyde $(1.5 \mathrm{~mL})$ was added in order to form a PVA-glutaraldehyde network [19]. Aliquots $(20 \mu \mathrm{L})$ of this mixture were transferred to 96 wells of a microplate containing $3.0 \mathrm{M} \mathrm{HCl}(120 \mu \mathrm{L})$ and kept at $25^{\circ} \mathrm{C}$ for $24 \mathrm{~h}$, after which the discs were formed (PVAG synthesis). Afterwards, the discs were removed and incubated with $0.61 \mathrm{M}$ ammonium persulphate, prepared in $2.0 \mathrm{M} \mathrm{HCl}$, for $30 \mathrm{~min}$. Then, they were incubated with $0.44 \mathrm{M}$ aniline for $60 \mathrm{~min}$ (PVAG coating with polyaniline: PVAG-PANI). Finally, the PVAG-PANI discs were activated using 2.5\% (v/v) glutaraldehyde for $60 \mathrm{~min}$ and exhaustively washed with $0.1 \mathrm{M}$ phosphate buffer, pH 6.0 (PVAG-PANIG synthesis). This process yielded 240 discs (wet) weighting about $15 \mathrm{mg}$ each.

2.3. HRP Immobilization. One disc of PVAG-PANIG was incubated with HRP $\left(1.0 \mathrm{~mL}\right.$ containing $12,500 \mathrm{U} \mathrm{mL}^{-1}$; $7 \mu \mathrm{g} \mathrm{mL}^{-1}$ prepared in different solutions of $0.1 \mathrm{M}$ sodium acetate buffer at $\mathrm{pH} 4.0-5.5$ or phosphate buffer at $\mathrm{pH}$ 6.0-7.5) for $60 \mathrm{~min}$, under orbital shaking $(80 \mathrm{rpm})$ at $4^{\circ} \mathrm{C}$. Afterwards, the immobilized enzyme on the HRP-PVAG disc, from now on abbreviated as PVAG-PANIG-HRP, was washed 3 -folds with $0.1 \mathrm{M}$ sodium acetate or phosphate buffer, twice with $1.0 \mathrm{M} \mathrm{NaCl}$ and twice with the same buffer. Discs of PVAG were used to immobilize HRP in the same conditions described above. HRP activity was not detected in the final washing buffer.

2.4. Enzyme Determinations. The activities of the soluble and immobilized HRP were established according to Halpin et al. [20] using pyrogallol and $\mathrm{H}_{2} \mathrm{O}_{2}$ as substrates. Briefly, either one disc of PVAG-PANIG-HRP $(15.0 \mathrm{mg})$ or $0.1 \mathrm{~mL}$ of soluble HRP $\left(874 \mathrm{U} \mathrm{mL}^{-1}\right)$ was incubated at room temperature $\left(28^{\circ} \mathrm{C}\right)$ with $0.5 \mathrm{~mL}$ of $12.69 \mathrm{mM}$ pyrogallol $(0.5 \mathrm{~mL})$, $5.0 \mathrm{mM} \mathrm{H} \mathrm{O}_{2}(0.25 \mathrm{~mL})$ prepared in $0.1 \mathrm{M}$ sodium acetate buffer, $\mathrm{pH} 4.5$, or $0.1 \mathrm{M}$ sodium phosphate buffer, $\mathrm{pH}$ $7.0(1.4 \mathrm{~mL}$ ), and after one min (soluble HRP) or $10 \mathrm{~min}$ (PVAG-PANIG-HRP) the formed product (purpurogallin) was spectrophotometrically established at $420 \mathrm{~nm}$ (Ultrospec 2000, GE Health Care). One unit of enzyme activity $(U)$ was defined as the amount of enzyme capable of oxidizing one micromole of pyrogallol per minute under experimental conditions $\left(\varepsilon=961 \mathrm{M} \mathrm{cm}^{-1}\right)$.

2.5. Immobilization Optimization Conditions. The PVAGPANIG-HRP disc was synthesized as above described using enzyme concentration varying from 0.502 to $0.912 \mu \mathrm{g} \mathrm{mL}^{-1}$. Increasing amounts of HRP prepared in $0.1 \mathrm{M}$ sodium phosphate buffer, $\mathrm{pH} 7.0$ were incubated with the PVAGPANIG disc for $60 \mathrm{~min}$ at $4^{\circ} \mathrm{C}$. The derivative was washed 3-folds with $0.1 \mathrm{M}$ sodium acetate buffer $\mathrm{pH}$ 5.0, followed by twice with $1.0 \mathrm{M} \mathrm{NaCl}$ and twice with the same buffer. The PVAG-PANIG-HRP disc activity was established and the retained protein estimated by the difference between offered protein and that found in the washing solutions. Firstly, the optimum $\mathrm{pH}$ was established incubating samples of soluble HRP with PVAG-PANIG discs, in the appropriated buffer (4.0-5.5 using $0.1 \mathrm{M}$ sodium acetate buffer and 6.07.5 using $0.1 \mathrm{M}$ sodium phosphate buffer). After that, the incubation time (30-210 min) was optimized. After washing the PVAG-PANIG-HRP discs their activities were measured as described above. All of these experiments were performed in triplicates and the results expressed as mean \pm standard deviation.

2.6. Immobilized HRP Properties. The following properties of the soluble and immobilized HRP (preparation synthesized under the best conditions) were investigated: the time course of the pyrogallol oxidation, the activity of the preparations as above described at $\mathrm{pH}$ varying from 3.5 to 7.0 (3.5-5.5 using $0.1 \mathrm{M}$ acetate buffer and 6.0-7.0 using $0.1 \mathrm{M}$ sodium phosphate buffer) and at temperatures varying from $30^{\circ} \mathrm{C}$ to $60^{\circ} \mathrm{C}$. Soluble HRP $(0.1 \mathrm{~mL})$ or one disc of PVAG-PANIGHRP were incubated with $12.69 \mathrm{mM}$ pyrogallol $(0.5 \mathrm{~mL})$, $5 \mathrm{mM} \mathrm{H}_{2} \mathrm{O}_{2}(0.25 \mathrm{~mL})$ either at the indicated $\mathrm{pH}, 28^{\circ} \mathrm{C}$, or at the indicated temperatures, $\mathrm{pH}$ 4.5. Then, after either $1 \mathrm{~min}$ (soluble) or $10 \mathrm{~min}$ (immobilized), aliquots were 
withdrawn and the formed product (purpurogallin) spectrophotometrically established at $420 \mathrm{~nm}$. One enzyme unit (U) was defined as the amount of HRP capable of forming $1 \mu \mathrm{mol}$ of purpurogallin per min.

The thermal stability of both free $(0.1 \mathrm{~mL})$ and immobilized enzymes (one disc) was established by incubating the preparations at $50^{\circ} \mathrm{C}$ and $70^{\circ} \mathrm{C}$. Samples were then withdrawn at time intervals (15-45 $\mathrm{min}$ ) and after equilibration at $37^{\circ} \mathrm{C}$ their activities were determined as described above. Kinetics was evaluated by assaying the preparation activities at pyrogallol concentrations varying from 4.0 to $48.7 \mathrm{mM}$. The HRP activity versus pyrogallol concentration was plotted. In order to estimate apparent Vmax and $\mathrm{Km}$, a nonlinear regression (hyperbolic fit) was performed, using Sigmaplot 2000, version 6 (Systat Software Inc., USA). The reuse of the immobilized enzyme was evaluated by assaying the same preparation seven times and washing it with buffer $(0.1 \mathrm{M}$ sodium acetate, $\mathrm{pH} 4.5)$ between each procedure. Finally, the shelf life was analyzed by keeping several PVAGPANIG-HRP discs in $0.1 \mathrm{M}$ acetate buffer, $\mathrm{pH} 4.5$, at $4^{\circ} \mathrm{C}$ and assaying the stored disc activity every seven days up to 80 days. The $100 \%$ value was established as the activity at the initial incubation time. All of these experiments were performed in triplicates and the results expressed as mean \pm standard deviation. Figures $2-6$ were plotted using Sigmaplot 2000, version 6 (Systat Software Inc., USA).

2.7. Treatment of Phenolic Compounds by the Soluble and PVAG-PANIG-HRP Disc. The soluble enzyme $(0.1 \mathrm{~mL})$ and PVAG-PANIG-HRP (one disc) containing both similar activity (about $90 \mathrm{U}$ ) were incubated at $37^{\circ} \mathrm{C}$ for $1.5 \mathrm{~h}$ with $0.1 \mathrm{mM}$ sodium acetate buffer $(2.0 \mathrm{~mL}), \mathrm{pH} 4.5$, containing $0.75 \mathrm{mmol} \mathrm{H}_{2} \mathrm{O}_{2}$ and $1.0 \mathrm{mM}$ of the following phenolic compounds: resorcinol; $\mathrm{m}$-cresol; catechol; pyrogallol; aniline; phenol; $\alpha$-naphthol; $\beta$-naphthol; $4,4^{\prime}$-diaminodiphenyl benzidine; 2-nitrosonaphthol. Afterwards, the remaining phenolic compounds were spectrophotometrically $(750 \mathrm{~nm})$ established according to Lowry et al. [21] and compared with the amount found in the untreated phenolic solutions $(100 \%)$. All these experiments were performed in triplicates and the results expressed as mean \pm standard deviation.

\section{Results and Discussion}

The PVAG-PANIG disc synthesis is carried out in two steps: firstly, a network of polyvinyl alcohol molecules is formed using glutaraldehyde as an arm under acid catalysis $[16,19]$ yielding the disc, which is coated with polyaniline chemically synthesized from aniline [13]. The PVAG and PVAG-PANIG discs presented $4.0 \mathrm{~mm}$ in diameter due to the microplate wells used as mold (Figure 1).

Thus the HRP is covalently fixed onto the PVAGPANIG disc via glutaraldehyde. It is important to notice that the physical shape of the PVAG occurs depending on the template used during the synthesis. Here, the wells of a microplate were used and therefore discs were obtained. However, PVAG was already used for plasticizing filter paper, which was used as a matrix for protein immobilization [18]. The moldability, flexibility, biocompatibility, and adhesive

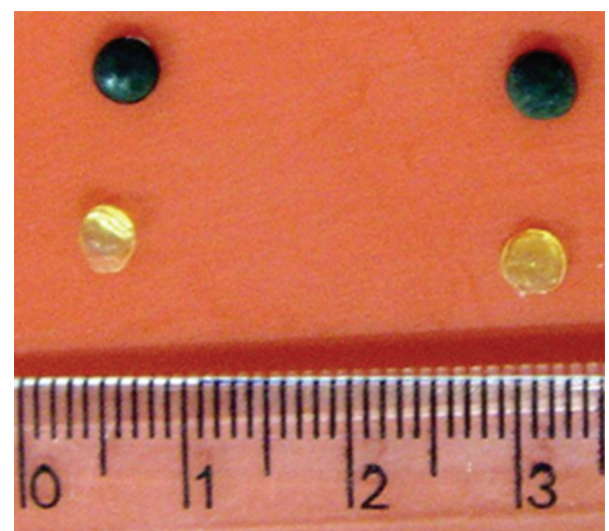

Figure 1: Disc of polyvinyl alcohol-glutaraldehyde-PVAG (yellow) and coated with polyaniline-PVAG-PANIG (dark-green).

property of PVA make it a versatile material for bioengineering. Recovering PVA with PANI increases the superficial area of this composite material and hence the protein loading, as mentioned by Caramori et al. [22] .

Figure 2 shows the relationship between the offered HRP and the immobilized enzyme expressed in terms of retained activity, protein per disc, and activity per mg of retained protein (specific activity). It is worthwhile to notice that the PVAG disc itself has carbonyl groups available $[16,17]$ for the HRP immobilization. However, the glutaraldehydetreated PANI coat would increase these available groups as demonstrated by the increased activity of the PVAG-PANIGHRP disc compared to that found for the PVAG-HRP preparation (Figure 2(a)). This is also reflected by the difference on the specific activity between them (Figure 2(b)). Intriguingly, the difference in terms of retained protein is negligible (Figure 2(b)). Therefore, one can admit that the PANI coating provides some advantage to the PVAG disc as far as the HRP immobilization is concerned. According to this result there, is a linear relationship between the offered HRP and the catalytically active immobilized HRP per disc (Figure 2(a)). However, this correlation is not followed by the specific activity (Figure 2(b)), which showed a hyperbolic curve suggesting that there is a limit after which inactive enzyme molecules are immobilized. Steric hindrance due to the overloading could be probably attributed to this effect. To avoid this phenomenon, all experiments to characterize the immobilized enzyme were carried out using a preparation synthesized with $7.0 \mu \mathrm{g} \mathrm{mL}^{-1}$ of the soluble HRP instead $1.0 \mathrm{mg} \mathrm{mL}^{-1}$.

Recovering of PVAG with PANIG improved its capability for HRP immobilization 24.6\% (PVAG 1,155 $\mathrm{Udisc}^{-1}$ against PVAG-PANIG 1,533 $\mathrm{Udisc}^{-1}$ ). The effectiveness of this material can be better demonstrated when comparing it with PET-PANIG, another composite tested for HRP immobilization [15]. PVAG-PANIG presented 9,650 more active immobilized HRP than PET-PANIG (PVAG-PANIG = $1,219,935.540 \mathrm{U} \mathrm{cm}^{-2}$ versus PET-PANIG $\left.=126.41 \mathrm{U} \mathrm{cm}^{-2}\right)$. Caramori et al. [22], based on UV-Vis spectra, surface area porosimetry, and scanning electron microscopy analyses, 


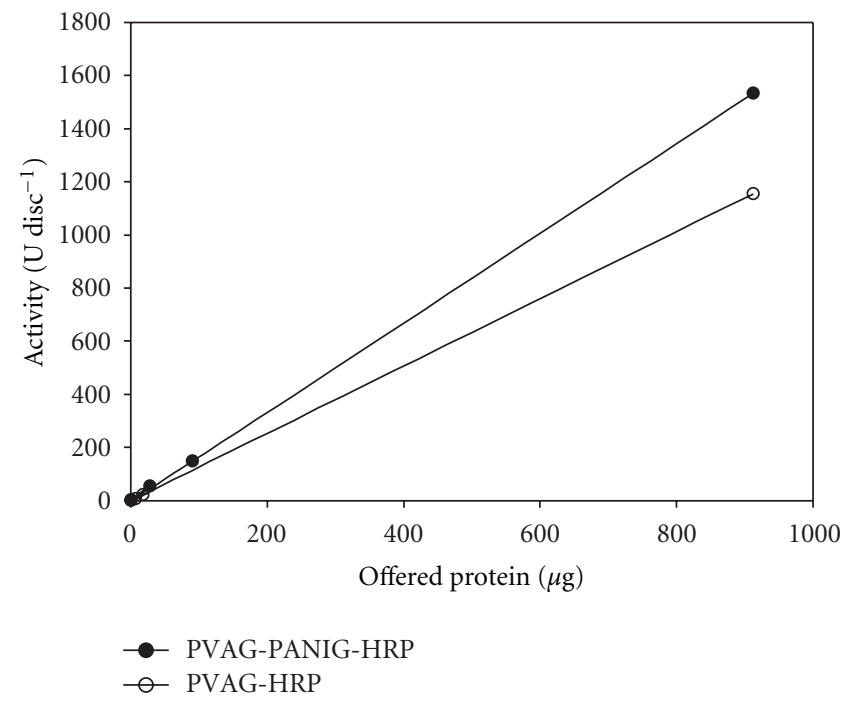

(a)

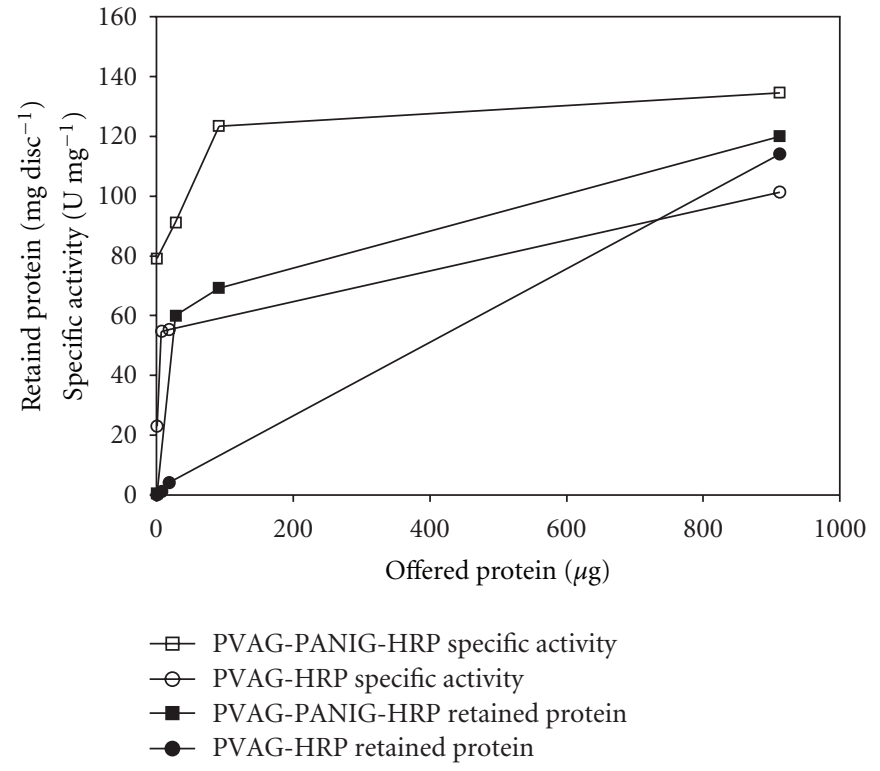

(b)

FIGURE 2: Relationship between offered and retained activity (a), protein (b), and specific activity (b) of the immobilized HRP on the PVAGPANIG disc.

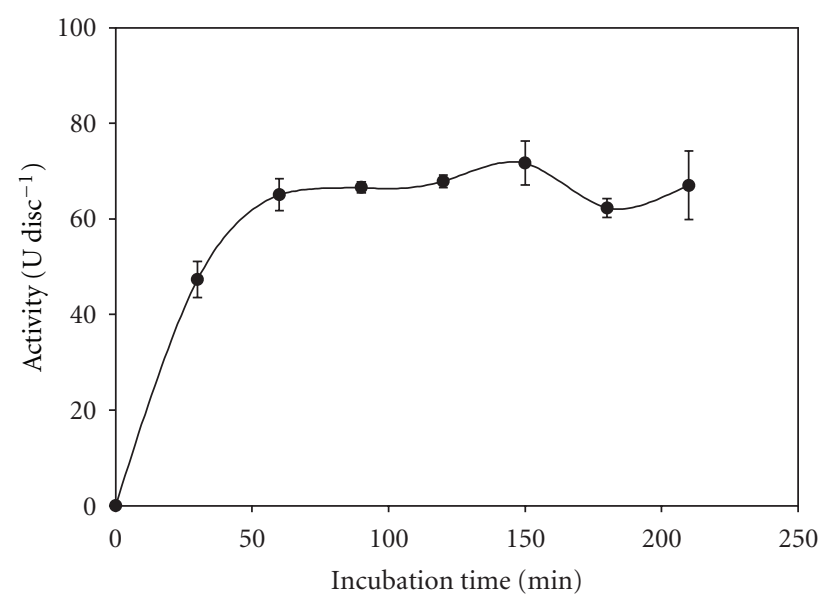

(a)

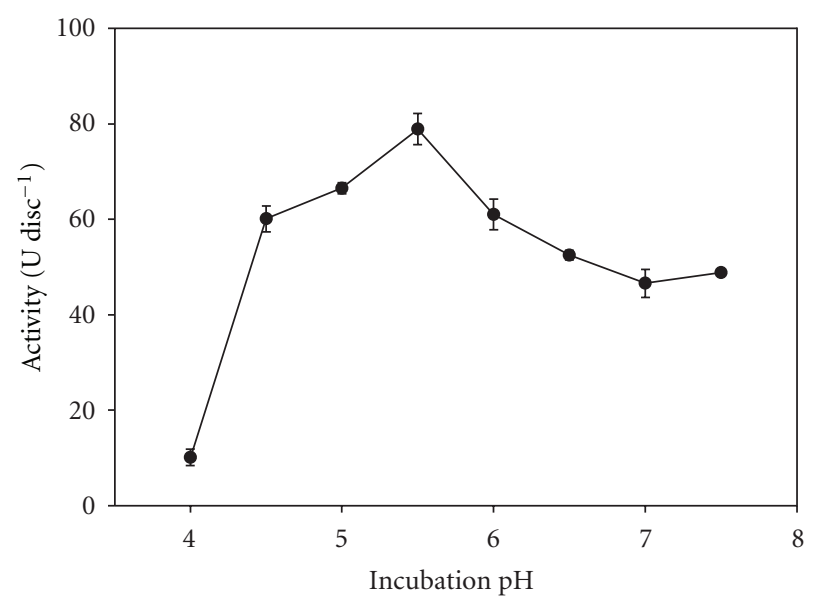

(b)

Figure 3: Optima time (a) and pH (b) for the immobilization of the soluble HRP on the PVAG-PANIG.

reported the PVAG-PANIG disc as a macroporous structure. The authors concluded this macroporous aspect due to PANI coating.

Figure 3(a) shows that $60 \mathrm{~min}$ is the best incubation time for the derivative PVAG-PANIG-HRP synthesis, after which longer incubation does not increase the catalytic activity of the immobilized enzyme. This time depends on the support and/or chemical groups involved in the HRP immobilization on different materials $[23,24]$. In the case of PANIG, the immobilization of HRP requires generally $60 \mathrm{~min}[6,13]$.

The best $\mathrm{pH}$ immobilization value of 5.5 for the HRP immobilization on PVAG-PANIG is shown in Figure 3(b). This $\mathrm{pH}$ value also depends on the support and/or chemical groups involved. Fernandes et al. [13] immobilizing HRP on PANIG reported a different optimum immobilization $\mathrm{pH}$ (6.0). This discrepancy can be probably attributed to the PVAG influence.

The time course of the pyrogallol oxidation catalyzed by the soluble and PVAG-PANIG-HRP disc showed that under the established experimental conditions a semilog plot (first order kinetics) was attained at the 1st and 10th minute, respectively (data not shown). Furthermore, all substrate was oxidized after $30 \mathrm{~min}$ of incubation by using both preparations.

The $\mathrm{pH}$ profiles for the soluble and PVAG-PANIG-HRP activities are displayed in Figure 4(a). Higher $\mathrm{pH}$ values than 7.0 were not studied because of the pyrogallol "autoxidation". There is a marked difference of the $\mathrm{pH}$ influence 


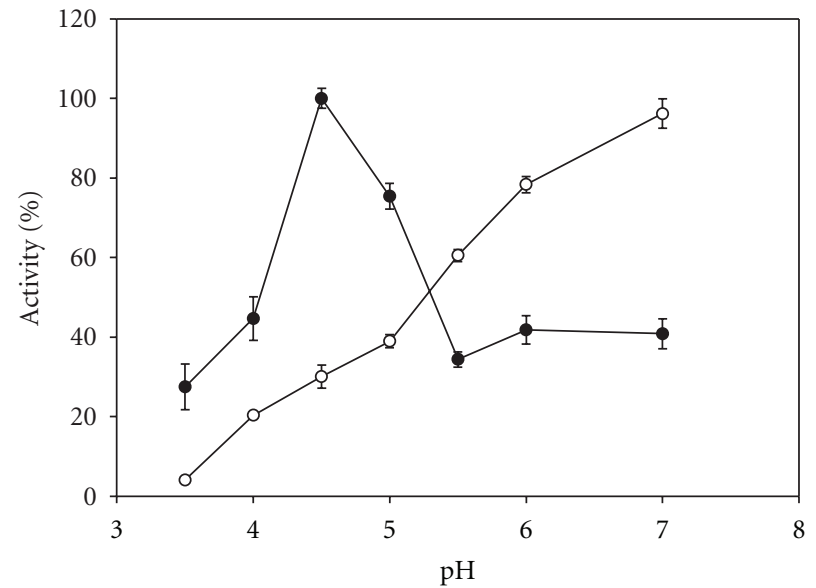

(a)

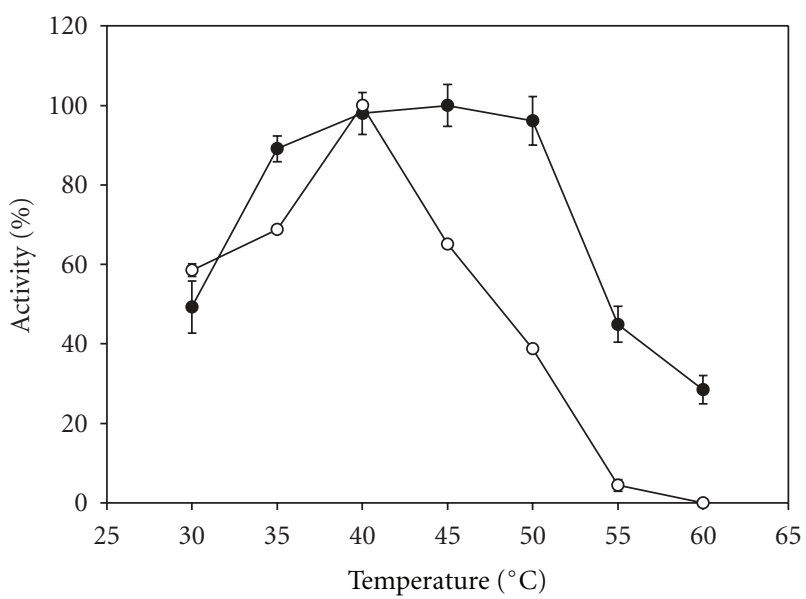

(b)

FIGURE 4: Influence of the $\mathrm{pH}(\mathrm{a})$ and temperature (b) on the soluble (०) and PVAG-PANIG-HRP $(\bullet)$.

on the enzyme activities. The immobilized enzyme presents optimum $\mathrm{pH}$ value at 4.5 whereas the soluble form at approximately 7.0 as already reported in the literature [25]. Fernandes et al. [14] reported a value of 7.0 for the HRP immobilized on PANI. Negatively and positively charged matrices are known to displace the $\mathrm{pH}$ profile towards to alkaline and acid $\mathrm{pH}$ values, respectively, as compared to the native enzymes, at low ionic strength. This left shift of optimum $\mathrm{pH}$ for the PVAG-PANIG-HRP suggests that the PVAG-PANIG presents positive charges on its surface. Li and Townshend [26] also reported different optimum $\mathrm{pH}$ for the HRP activity before (7.0) and after immobilization (5.8) on polytetrafluorethylene tubing.

The effect of the temperature on the soluble and PVAGPANIG-HRP is shown in Figure 4(b) and optimal temperatures were found to be $40^{\circ} \mathrm{C}$ and $40-50^{\circ} \mathrm{C}$, respectively. The decays of the descending arms of the curves denote different effects of the temperature on the soluble and immobilized enzyme. No activity was detected for the soluble enzyme assay at $60^{\circ} \mathrm{C}$, whereas the immobilized enzyme assay still presented some activity $\left(30 \%\right.$ of that at $\left.50^{\circ} \mathrm{C}\right)$. Similar results were reported by El-Essi et al. [27] and Lai and Lin [28] for HRP immobilized on sol-gel matrices and porous glass, respectively. Further evidences for the higher thermal stability for the PVAG-PANIG-HRP can be seen in Figure 5 which showed that the soluble enzyme activity decreased faster than the immobilized preparation when both were incubated at $50^{\circ} \mathrm{C}$ and $70^{\circ} \mathrm{C}$. The soluble enzyme lost all activity after $15 \mathrm{~min}$ at $70^{\circ} \mathrm{C}$, whereas the immobilized one retained about $20 \%$ of its initial activity. Increase of the thermal resistance after HRP immobilization has already been reported in the literature [24, 29-31].

The action of the soluble and PVAG-PANIG-HRP on pyrogallol followed the Michaelis-Menten kinetics. Values of apparent Michaelis constants were estimated to be $5.47 \pm 0.71 \mathrm{mM}$ and $12.07 \pm 1.35 \mathrm{mM}$ for the soluble and immobilized HRP (apparent value), respectively. This discrepancy showed to be statistically different

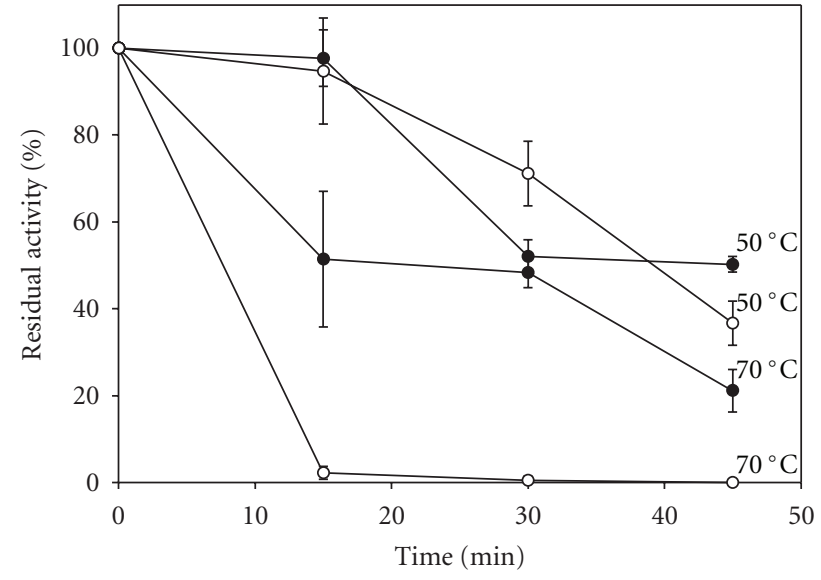

Figure 5: Thermal stability at $50^{\circ} \mathrm{C}$ and $70^{\circ} \mathrm{C}$ for the soluble (०) and PVAG-PANIG-HRP $(\bullet)$.

( $t=1.92$ and $P=0.03)$. Conformational/steric, partitioning, diffusional/mass-transfer, and microenvironmental effects are well known to influence immobilized enzyme kinetics. Kinetic parameters, particularly, the apparent Km, can provide the degree of these interferences when compared to that calculated for the soluble enzyme. This apparent constant usually increases as the result of impairment of the enzyme action under those effects.

The reuse of the PVAG-PANIG-HRP is presented in Figure 6(a). The same disc was used three times without activity loss and retained $25 \%$ of the initial activity after the 7th use. It is worthwhile to draw attention to the fact that this preparation was incubated with $\mathrm{H}_{2} \mathrm{O}_{2}$, a traditional HRP inhibitor and protein denaturing agent. The HRP derivatives (aluminum-pillared interlayered clay-HRP with addition of polyethylene glycol) synthesized by Cheng et al. [32], showed to be not reusable were and Akhtar et al. [33] reported poorer performance reusing immobilized bitter gourd peroxidase on Sephadex G-50. The storage stability (shelf life) of 


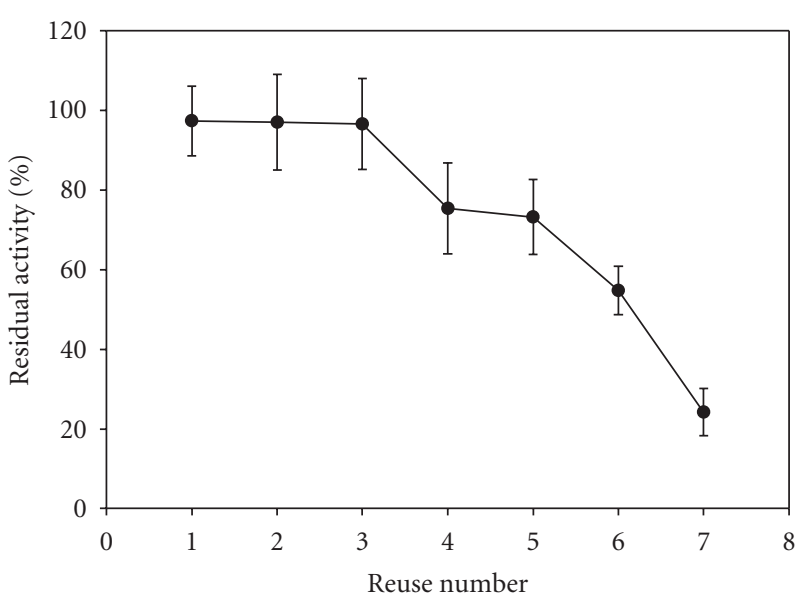

(a)

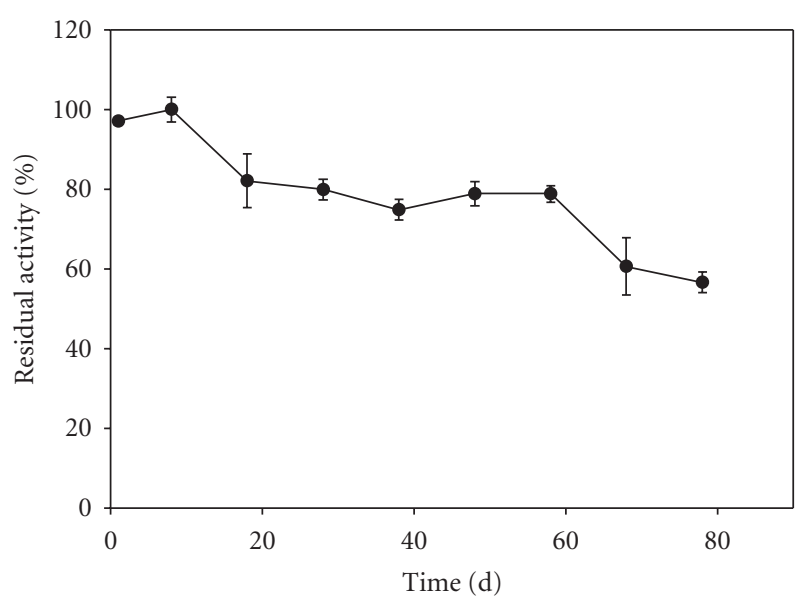

(b)

Figure 6: Reuse (a) and shelf life (b) of PVAG-PANIG-HRP.

the PVAG-PANIG-HRP was investigated for 80 days at $4^{\circ} \mathrm{C}$ in $0.1 \mathrm{M}$ sodium acetate buffer, $\mathrm{pH} 4.5$ and Figure 6(b) resumes the results. The immobilized enzyme derivative retained approximately $80 \%$ and $60 \%$ of its initial activity after 60 and 80 days of storage, respectively. This behavior is superior to those reported by Rojas-Melgarejo et al. [34] and Cheng et al. [32].

The enzymatic approach has attracted much interest in the decolorization/degradation of textile and other industrially important dyes from wastewater as an alternative strategy to conventional chemical, physical and biological treatments [35]. Cheng et al. [32] removed, after $4 \mathrm{~h}$, more than $90 \%$ of phenol using polyethylene glycol as aluminumpillared-interlayered clay-peroxidase stabilizer in the reaction medium. The ability of the soluble HRP and PVAG-PANIGHRP disc to remove phenolic compounds up to $1.5 \mathrm{~h}$ is demonstrated in the Table 1 . Most of them were efficiently oxidized by both soluble and immobilized enzyme and no stabilizer was added. Pyrogallol, $\alpha$-naphthol, catechol, $\beta$ naphthol, 4,4' -diaminodiphenyl benzidine, $\mathrm{m}$-cresol, resorcinol, and 2-nitrosonaphthol were oxidized by the PVAGPANIG-HRP disc in percents varying from $70 \%$ to $90 \%$, except for 2-nitrosonaphthol (c.a. 18\%). As mentioned above, pyrogallol was completely oxidized after $30 \mathrm{~min}$ of incubation by both enzymatic preparations. Therefore, the reusability and higher thermal stability of the PVAG-PANIGHRP disc would offer advantage compared to the soluble enzyme. The PVAG-PANIG-HRP disc showed to be more efficient than the immobilized bitter gourd (Momordica charantia) peroxidase on Con A adsorbed-Sephadex G 50 [10]. According to these authors, resorcinol, m-cresol, catechol, pyrogallol, under similar experimental conditions, were only removed $18 \%, 11 \%, 45 \%$, and $0 \%$, respectively.

Both enzymatic preparations showed to be less efficient towards aniline and phenol. However, the immobilized HRP presented better performance than soluble form. Different results were obtained with the immobilized bitter gourd peroxidase, which was more efficient to remove phenol (about 90\%) than PVAG-PANIG-HRP disc (about 35\%).
TABle 1: Phenolic compounds oxidation by the soluble and HRPPVG-PANIG.

\begin{tabular}{lcc}
\hline Phenolic compounds & \multicolumn{2}{c}{ Oxidation (\%) } \\
\hline & Soluble HRP & HRP-PVAG-PANIG \\
Pyrogallol & $92.1 \pm 0.3$ & $92.1 \pm 1.1$ \\
$\alpha$-Naphthol & $87.6 \pm 0.1$ & $90.0 \pm 1.2$ \\
Catechol & $81.3 \pm 0.4$ & $86.5 \pm 0.2$ \\
$\beta$-Naphthol & $78.0 \pm 0.2$ & $83.2 \pm 0.8$ \\
4,4'-Diaminodiphenyl & $72.4 \pm 1.8$ & $75.1 \pm 0.5$ \\
benzidine & $62.0 \pm 0.9$ & $71.0 \pm 0.4$ \\
m-Cresol & $75.0 \pm 0.3$ & $70.8 \pm 0.1$ \\
Resorcinol & $28.4 \pm 1.0$ & $45.0 \pm 3.7$ \\
Aniline & $15.5 \pm 0.9$ & $35.8 \pm 1.3$ \\
Phenol & $18.8 \pm 2.5$ & $19.7 \pm 2.4$ \\
2-Nitrosonaphthol &
\end{tabular}

\section{Conclusions}

More than 200 discs of the network polyvinyl alcohol-glutaraldehyde (PVAG) coated with polyaniline (PANIG) can be synthesized by a simple and inexpensive procedure. HRP can also be covalently fixed onto these discs via glutaraldehyde (PVAG-PANIG-HRP disc). The immobilization efficiency of this material was more than 9,000 fold higher than the obtained with PET-PANIG composite. The optimum $\mathrm{pH}$ of the PVAG-PANIG-HRP disc is lower than that reported for the soluble enzyme, whereas the optimum temperature is higher. The PVAG-PANIG-HRP disc is more thermal resistant than the soluble enzyme. The same PVAG-PANIGHRP disc can be reused and stored for months without significant activity loss. Resorcinol, $\mathrm{m}$-cresol, catechol, pyrogallol, $\alpha$-naphthol, $\beta$-naphthol, and 4,4'-diaminodiphenyl benzidine are efficiently oxidized by the PVAG-PANIG-HRP disc (approximately about 60\% to 90\%), while aniline, phenol, and 2-nitrosonaphthol are less efficiently oxidized. The flexibility of PVA and the advantages obtained in 
the immobilization procedure make the PVAG-PANIG composite a possible target for applications in the treatment of wastewater.

\section{Acknowledgments}

The authors are thankful to the Brazilian National Research Council (CNPq) for financing this research and Dr. Elba Bon for providing the peroxidase.

\section{References}

[1] M. Shakeri and M. Shoda, "Efficient decolorization of an anthraquinone dye by recombinant dye-decolorizing peroxidase (rDyP) immobilized in silica-based mesocellular foam," Journal of Molecular Catalysis B, vol. 62, no. 3-4, pp. 277-281, 2010.

[2] V. Yousefi and H. R. Kariminia, "Statistical analysis for enzymatic decolorization of acid orange 7 by Coprinus cinereus peroxidase," International Biodeterioration and Biodegradation, vol. 64, no. 3, pp. 245-252, 2010.

[3] V. S. Houk, "The genotoxicity of industrial wastes and effluents: a review," Mutation Research, vol. 277, no. 2, pp. 91-138, 1992.

[4] K. T. Chung and C. E. Cerniglia, "Mutagenicity of azo dyes: structure-activity relationships," Mutation Research, vol. 277, no. 3, pp. 201-220, 1992.

[5] V. Sanz, S. de Marcos, and J. Galbán, "Direct glucose determination in blood using a reagentless optical biosensor," Biosensors and Bioelectronics, vol. 22, no. 12, pp. 2876-2883, 2007.

[6] F. M. Lopes, S. Mitidieri, and K. F. Fernandes, "A minireactor for glucose analysis in human serum samples," Revista Processos Químicos, vol. 2, pp. 83-88, 2008.

[7] H. H Yu, G. S. Ginsbrug, and N. Harris, "Evaluation and clinical application of a direct low density lipoprotein cholesterol assay in normolipemic and hyperlipidemic adults," American Journal of Cardiology, vol. 80, pp. 1295-1299, 1997.

[8] S. Singh, P. R. Solanki, M. K. Pandey, and B. D. Malhotra, "Cholesterol biosensor based on cholesterol esterase, cholesterol oxidase and peroxidase immobilized onto conducting polyaniline films," Sensors and Actuators B, vol. 115, no. 1, pp. 534-541, 2006.

[9] F. Mizutani, S. Yabuki, Y. Sato, T. Sawaguchi, and S. Iijima, "Amperometric determination of pyruvate, phosphate and urea using enzyme electrodes based on pyruvate oxidasecontaining poly(vinyl alcohol)/polyion complex-bilayer membrane," Electrochimica Acta, vol. 45, no. 18, pp. 2945-2952, 2000.

[10] S. Akhtar and Q. Husain, "Potential applications of immobilized bitter gourd (Momordica charantia) peroxidase in the removal of phenols from polluted water," Chemosphere, vol. 65, no. 7, pp. 1228-1235, 2006.

[11] T. S. Shaffiqu, J. J. Roy, R. A. Nair, and T. E. Abraham, "Degradation of textile dyes mediated by plant peroxidases," Applied Biochemistry and Biotechnology A, vol. 102-103, pp. 315-326, 2002.

[12] A. A. Khan and Q. Husain, "Decolorization and removal of textile and non-textile dyes from polluted wastewater and dyeing effluent by using potato (Solanum tuberosum) soluble and immobilized polyphenol oxidase," Bioresource Technology, vol. 98, no. 5, pp. 1012-1019, 2007.
[13] K. F. Fernandes, C. S. Lima, H. Pinho, and C. H. Collins, "Immobilization of horseradish peroxidase onto polyaniline polymers," Process Biochemistry, vol. 38, no. 9, pp. 1379-1384, 2003.

[14] K. F. Fernandes, C. S. Lima, F. M. Lopes, and C. H. Collins, "Properties of horseradish peroxidase immobilised onto polyaniline," Process Biochemistry, vol. 39, no. 8, pp. 957-962, 2004.

[15] S. S. Caramori and K. F. Fernandes, "Covalent immobilisation of horseradish peroxidase onto poly(ethylene terephthalate)poly(aniline) composite," Process Biochemistry, vol. 39, no. 7, pp. 883-888, 2004.

[16] A. M. Araújo, M. T. Neves Jr., W. M. Azevedo et al., "Polyvinyl alcohol-glutaraldehyde network as a support for protein immobilization," Biotechnology Techniques, vol. 112, pp. 6772, 1996.

[17] L. B. Carvalho Jr., A. M. Araújo, A. M. P. Almeida, and W. M. Azevedo, "The use of polyvinyl alcohol glutaraldehyde antigen coated discs for laser induced fluorescence detection of plague," Sensors and Actuators B, vol. 36, no. 1-3, pp. 427-430, 1996.

[18] G. H. T. S. Barbosa, E. M. Santana, A. M. P. Almeida, A. M. Araújo, O. Fatibello-Filho, and L. B. Carvalho Jr., "The use of filter paper plasticized with polyvinyl alcohol-glutaraldehyde in ELISA," Brazilian Journal of Medical and Biological Research, vol. 33, no. 7, pp. 823-827, 2000.

[19] S. S. Caramori, F. N. De Faria, M. P. Viana, K. F. Fernandes, and L. B. Carvalho Jr., "Trypsin immobilization on discs of polyvinyl alcohol glutaraldehyde/ polyaniline composite," $\mathrm{Ma}$ terials Science and Engineering C, vol. 31, no. 2, pp. 252-257, 2011.

[20] B. Halpin, R. Pressey, J. Jen, and N. J. Mondy, "Purification and characterization of peroxidase isoenzymes from green peas (Pisum sativum)," Journal of Food Science, vol. 54, pp. 644-669, 1989.

[21] O. H. LOWRY, N. J. ROSEBROUGH, A. L. FARR, and R. J. RANDALL, "Protein measurement with the Folin phenol reagent," The Journal of Biological Chemistry, vol. 193, no. 1, pp. 265-275, 1951.

[22] S. S. Caramori, K. F. Fernandes, and L. B. Carvalho Jr., "Synthesis and characterization of polyvinyl alcohol-polyanilineglutaraldehyde composite disc: a probable matrix for protein immobilization," Revista Processos Químicos, vol. 7, pp. 46-52, 2010.

[23] Z. M. Liu, S. Tingry, C. Innocent, J. Durand, Z. K. Xu, and P. Seta, "Modification of microfiltration polypropylene membranes by allylamine plasma treatment. Influence of the attachment route on peroxidase immobilization and enzyme efficiency," Enzyme and Microbial Technology, vol. 39, no. 4, pp. 868-876, 2006.

[24] F. Rojas-Melgarejo, J. N. Rodríguez-López, F. García-Cánovas, and P. A. García-Ruiz, "Cinnamic carbohydrate esters: new polymeric supports for the immobilization of horseradish peroxidase," Carbohydrate Polymers, vol. 58, no. 1, pp. 79-88, 2004.

[25] B. Chance and A. C. Maehly, "Assay of catalases and peroxidases," Methods in Enzymology, vol. 2, pp. 764-775, 1955.

[26] Y. Z. Li and A. Townshend, "Evaluation of the adsorptive immobilisation of horseradish peroxidase on PTFE tubing in flow systems for hydrogen peroxide determination using fluorescence detection," Analytica Chimica Acta, vol. 359, no. 1-2, pp. 149-156, 1998. 
[27] F. A. El-Essi, A. Z. Abu Zuhri, S. I. Al-Khalil, and M. S. Abdel-Latif, "Spectrophotometric determination of enzymatically generated hydrogen peroxide using Sol-Gel immobilized horseradish peroxidase," Talanta, vol. 44, no. 11, pp. 20512058, 1997.

[28] Y. C. Lai and S. C. Lin, "Application of immobilized horseradish peroxidase for the removal of $\mathrm{p}$-chlorophenol from aqueous solution," Process Biochemistry, vol. 40, no. 3-4, pp. 1167-1174, 2005.

[29] E. Miland, M. R. Smyth, and C. ÓFágáin, "Increased thermal and solvent tolerance of acetylated horseradish peroxidase," Enzyme and Microbial Technology, vol. 19, no. 1, pp. 63-67, 1996.

[30] U. Bora, P. Sharma, S. Kumar, K. Kannan, and P. Nahar, "Photochemical activation of a polycarbonate surface for covalent immobilization of a protein ligand," Talanta, vol. 70, no. 3, pp. 624-629, 2006.

[31] S. Musthapa, S. Akhtar, A. A. Khan, and Q. Husain, "An economical, simple and high yield procedure for the immobilization/stabilization of peroxidases from turnip roots," Journal of Scientific and Industrial Research, vol. 63, no. 6, pp. 540-547, 2004.

[32] J. Cheng, S. Ming Yu, and P. Zuo, "Horseradish peroxidase immobilized on aluminum-pillared interlayered clay for the catalytic oxidation of phenolic wastewater," Water Research, vol. 40, no. 2, pp. 283-290, 2006.

[33] S. Akhtar, A. A. Khan, and Q. Husain, "Potential of immobilized bitter gourd (Momordica charantia) peroxidases in the decolorization and removal of textile dyes from polluted wastewater and dyeing effluent," Chemosphere, vol. 60, no. 3, pp. 291-301, 2005.

[34] F. Rojas-Melgarejo, J. N. Rodríguez-López, F. García-Cánovas, and P. A. García-Ruiz, "Immobilization of horseradish peroxidase on cinnamic carbohydrate esters," Process Biochemistry, vol. 39, no. 11, pp. 1455-1464, 2004.

[35] Q. Husain, "Potential applications of the oxidoreductive enzymes in the decolorization and detoxification of textile and other synthetic dyes from polluted water: a review," Critical Reviews in Biotechnology, vol. 26, no. 4, pp. 201-221, 2006. 

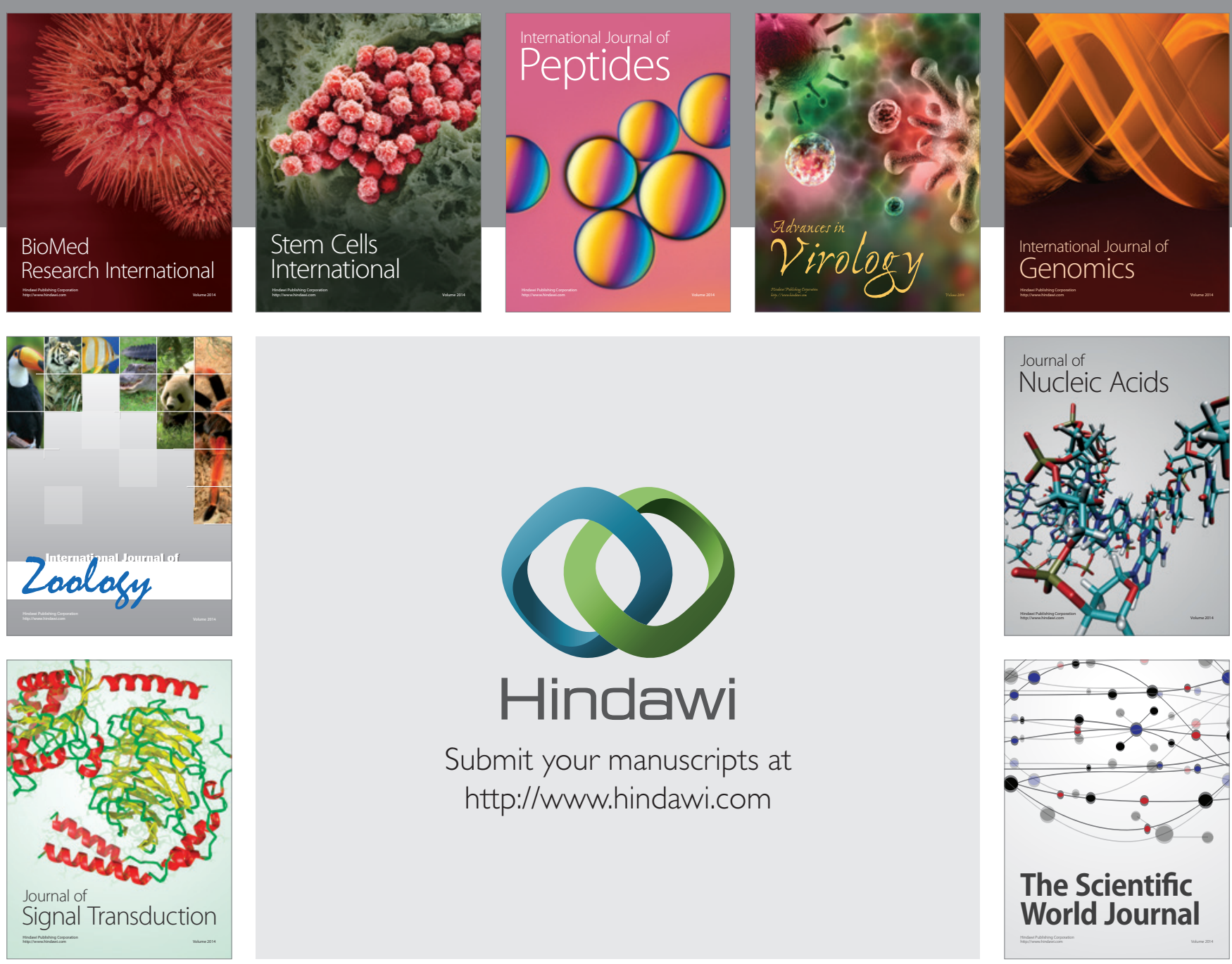

Submit your manuscripts at

http://www.hindawi.com
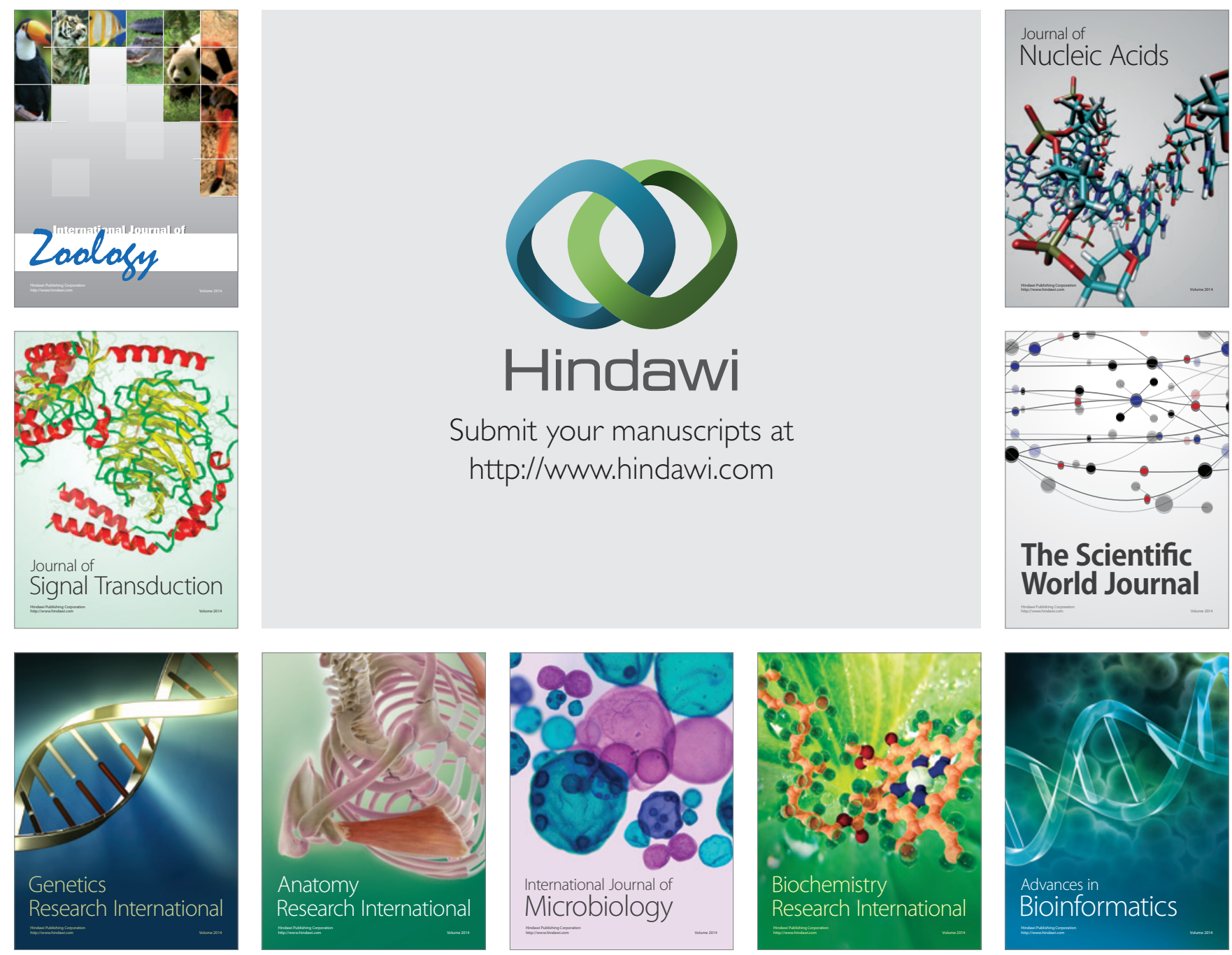

The Scientific World Journal
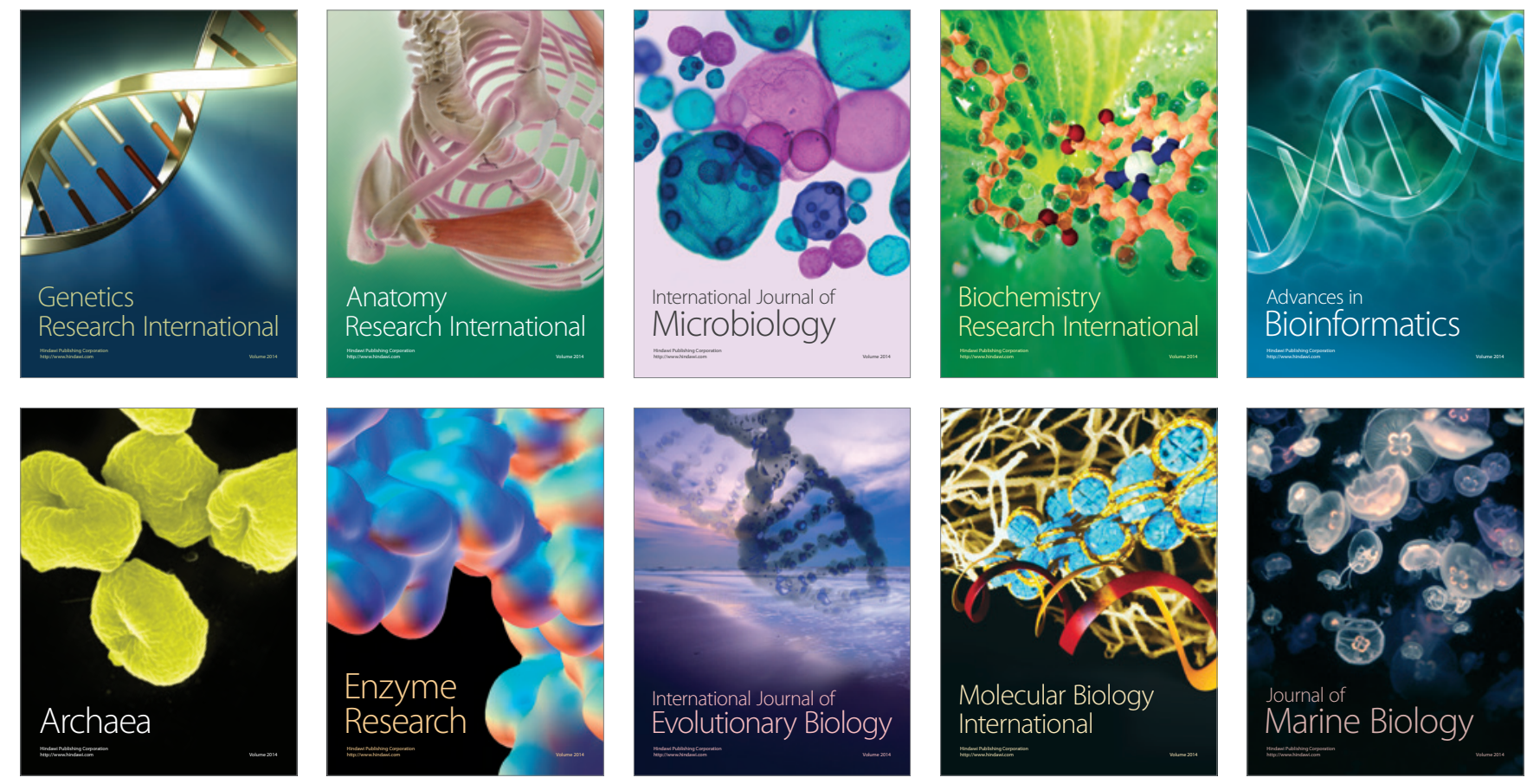